\title{
Coronary embolism causing acute myocardial infarction. Review of the literature
}

\section{Zator tętnic wieńcowych powodujący ostry zawat serca. Przegląd literatury}

\author{
Małgorzata Zachura', Łukasz Piątek', Jacek Kurzawski¹, Marianna Janion ${ }^{1,2}$ \\ ${ }^{12^{\text {nd }}}$ Department of Cardiology, Świętokrzyskie Cardiology Centre, Kielce, Poland \\ Head of the Department: Prof. Marianna Janion MD, PhD \\ 2Department of Internal Diseases, Cardiology and Medicine Nursing, Institute of Nursing and Obstetrics, Faculty of Health Sciences, \\ Jan Kochanowski University, Kielce, Poland \\ Head of the Department: Prof. Marianna Janion MD, PhD
}

Key words: cardiomyopathy, atrial fibrillation, acute myocardial infarction, coronary artery embolism, valve prosthesis.

Słowa kluczowe: kardiomiopatia, migotanie przedsionków, ostry zespół wieńcowy, zator tętnicy wieńcowej, proteza zastawki.

\begin{abstract}
Coronary artery embolism (CE) should be considered as a nonatherosclerotic cause of acute myocardial infarction (AMI), especially in patients with conditions favouring the formation of intracardiac thrombi. The main aetiologies of CE have changed in recent decades. Currently, atrial fibrillation is the most common cause. Most studies on CE infarcts are case reports with small numbers of patients. There are still no clear guidelines for the management in embolic myocardial infarction. Depending on the aetiology, the treatment needs to be tailored individually. As long-term outcomes indicate, patients with CE causing AMI are at high-risk and therefore require close follow-up.
\end{abstract}

\section{Streszczenie}

Zator tętnicy wieńcowej należy podejrzewać w przypadku ostrego zespołu wieńcowego u pacjentów bez choroby miażdżycowej, ale z czynnikami ryzyka sprzyjającymi powstawaniu skrzeplin wewnątrzsercowych. Najważniejsze etiologie zatoru tętnic wieńcowych zmieniały się w ciągu ostatnich dekad. Obecnie za najczęstszą przyczynę uznaje się migotanie przedsionków. Większość prac na temat zawałów spowodowanych zatorem tętnicy wieńcowej to opisy przypadków z niewielką liczbą przedstawionych pacjentów. Niestety nadal nie ma jasnych wytycznych co do diagnostyki oraz leczenia zatoru tętnic wieńcowych. W zależności od etiologii leczenie powinno być dopasowane indywidualnie. Jak wskazują wyniki długoterminowych obserwacji, pacjenci z zawałem w wyniku zatoru tętnicy wieńcowej stanowią grupę wysokiego ryzyka, która wymaga dokładnej obserwacji.

Approximately $5 \%$ of all patients with acute myocardial infarction (AMI) do not have atherosclerotic coronary artery disease [1]. Coronary artery embolism (CE) should be suspected in patients with factors or comorbidities predisposing to embolic events, who develop severe chest pain with elevated cardiac enzymes. Large diversity of aetiologies makes the precise diagnosis challenging. Most studies on coronary artery embolic infarcts are case reports with a small number of patients. There are still no clear guidelines for diagnostic criteria and the management of such cases. The approach of this paper is to provide a literature review of the CE causing AMI.

Results from research by Prizel et al. revealed the incidence of coronary artery embolic infarcts in
55 out of 419 patients, which comprised 13\% of autopsy-studied infarcts [2]. In another recent mechanistic study, based on analysis of 1776 patients with de novo AMI, the prevalence of CE was $2.9 \%$ [3]. The growing importance of invasive diagnostic and therapeutic methods provides a wealth of information about $\mathrm{CE}$ and its aetiology. There are a number of causes of coronary artery embolism. Analysis of the four main autopsy studies reported in the literature [4-6] with additional recently published mechanistic study [3], shows how the aetiology of $\mathrm{CE}$ has varied over the last half-century. Initially infective endocarditis accounted for more than half of all cases, then with the widespread use of antibiotics non-infected valvular heart disease became more frequent. However, recent stud- 
ies show that non-valvular atrial fibrillation (AF) with a low burden of atherosclerotic risk factors is probably the most common cause of $\mathrm{CE}[3,7]$. Less frequent but worth mentioning are: dilated cardiomyopathy, embolism by tumour, thrombus through a patent foramen ovale or atrial septal defect, iatrogenic embolism during interventional procedures, left ventricular aneurysm, non-infected thrombi on prosthetic valves, septic emboli from infective endocarditis, tumours, and cardiac surgery $[2,7]$.

Atrial fibrillation is associated with a high risk of thromboembolic events, the incidence and prevalence of this arrhythmia increase with aging [8]. The European Society of Cardiology (ESC) guidelines point towards $\mathrm{AMI}$ being linked to $\mathrm{CE}$, due to $\mathrm{AF}$ as a rare condition with probably underestimated frequency [9]. A recent study by Shibata et al. implicates AF as the most common cause of CE with more frequent incidence of chronic than paroxysmal AF in diagnosed patients (66\% vs. 34\%) [3]. Other data also suggest that thromboembolic potential of chronic lone AF in the small subset of patients is high enough to require anticoagulation, even in groups of people less than 50 years of age [8]. The risk of thromboembolic events in AF patients can be quantified by various scoring systems. The most commonly used $\mathrm{CHADS}_{2}$ and $\mathrm{CHA}_{2} \mathrm{DS}_{2}$-VASc help to identify moderate- to high-risk AF patients with recommendations to anticoagulant treatment. Studies suggest a similar clinical utility of both scores in predicting stroke and thromboembolism, but $\mathrm{CHA}_{2} \mathrm{DS}_{2}$-VASc has the important advantage of identifying extremely low-risk patients with AF, as well as classifying a lower proportion of patients as a moderate risk $[10,11]$. That means that many patients at low to moderate risk according to $\mathrm{CHADS}_{2}$ are actually in a higher risk category after reassessment using the $\mathrm{CHA}_{2} \mathrm{DS}_{2}$-VASc score. It was noticed by Shibata et al. that $60 \%$ of patients with non valvular AF had a CHADS 2 score of 0 or 1 before the onset of $\mathrm{CE}$, and after re-evaluation using the $\mathrm{CHA}_{2} \mathrm{DS}_{2}$-VASc score $61 \%$ of those patients were categorised into a higher risk category $(\geq 2)$ that would benefit from oral anticoagulation [3]. Therefore, precise stratification of AF patients (including preference of the $\mathrm{CHA}_{2} \mathrm{DS}_{2}$-VASc scoring system) has become a crucial determinant of optimal antithrombotic prophylaxis.

According to recent studies, cardiomyopathy is the next most common cause $(25 \%)$ of $\mathrm{CE}$, followed by valvular heart disease (15\%) [3]. Dilated cardiomyopathy favours the formation of intracardiac thrombi, a potential source of embolism. The examination of 45 patients with dilated cardiomyopathy with mild to moderate systolic dysfunction, who were at sinus rhythm and without anticoagulation therapy, revealed left ventricular thrombus in $13.3 \%$ and left atrial appendage thrombus in $68.9 \%$ [12]. Factors that predispose to thromboembolic events in patients with congestive heart failure $(\mathrm{CHF})$ include low cardiac output, with relative stasis of blood in dilated cardiac chambers, poor contractility, and regional wall motion abnormalities [13]. This means that patients with $\mathrm{CHF}$ are at high risk of subsequent embolism.

Patients with prosthetic valves are also at risk of thromboembolic complications. Mechanical prosthetic valves are highly thrombogenic, and thereby require life-long anticoagulation therapy with vitamin K antagonists (VKA) [14]. Lack of patient awareness of medication importance with no proper monitoring and dose adjustments poses a risk in prosthetic valve thrombosis and systemic thromboembolic events $[15,16]$. Coronary artery embolism is a potentially life-threatening occurrence in patients with heart valve prosthesis. Despite the risks, international normalised ratio (INR) values in patients chronically treated with oral anticoagulants are outside the therapeutic range for $34-60 \%$ of the time [16]. Likewise, a few reported cases show the correlation between the calcified native valves and CE resulting in AMI $[17,18]$. The medical records of 70 patients undergoing coronary arteriography for AMI with no coronary artery disease estimate that the incidence of CE originating from the left atrium or calcified aortic valve is 5.7\% [19].

Paradoxical coronary embolism (PCE) accounts for $10-15 \%$ of all paradoxical emboli, and $25 \%$ of acute coronary events in patients less than 35 years of age: a patent foramen ovale (PFO) or an atrial septal defect (ASD) has been occasionally described as a source of paradoxical embolism [19-22]. On the basis of published case reports there are some characteristic features helping in the diagnosis of MI due to PCE. These include: young age, risk factors predisposing hypercoagulating states (smoking, use of oral contraceptives), permanent right-to-left shunting on echocardiogram, systemic arterial emboli in the absence of left heart thrombus, thrombo-embolic material in the right heart or venous circulation, associated lung disease with elevation of right heart pressure or tiny myocardial infarction, but no or mild impairment of myocardial segmental kinesis and function [19, 23, 24].

As one of the most common causes of CE in the past, infective endocarditis (IE)-related AMI is well documented. However, even in an era of widespread use of antibiotics, coronary emboli from IE do still occur, and can present as ST-elevation myocardial infarction [25]. Studies have shown microemboli in the coronary arteries in $60 \%$ of patients with IE [25-27]. The diagnosis of IE has serious implications for the proper choice of therapeutic method in case of CE. There are several reports that warn about use of thrombolysis for AMI associated with endocarditis, due to risk of fatal intracranial bleeds and massive gastrointestinal bleeding [25-29].

Taking into consideration the main causes of $\mathrm{CE}$, it is noticeable that patients prone to AMI due to $\mathrm{CE}$ have a lower prevalence of hypertension, diabetes 
mellitus, dyslipidaemia, smoking, and a total number of major coronary risk factors in comparison to AMI in patients with CAD [3]. Patients with CE may have a history of other systemic emboli since the underlying conditions are those that predispose to systemic embolism as a whole. Almost two-thirds of clinicallydiagnosed emboli produce transmural infarction and one-third produce non-transmural infarction [30] In another study it was confirmed that ST elevation myocardial infarction (STEMI) accounted for $65 \%$ of all AMI caused by CE. However, this is less than in patients without $\mathrm{CE}$, where the incidence of STEMI is $80 \%$ [3]. The consequences of CE depend on both the size of the embolus and the size of the artery in which it becomes impacted [31]. According to Charles et al., CE usually affects the left coronary system because the left artery is larger than the right one [30] However, a recent study revealed no significant differences in the distribution of both coronary systems' involvement, and the incidence of multiple coronary embolisation is estimated at 15\% [3]. A curious feature of coronary emboli that has been long recognised is that they most frequently lodge in the distal parts of the coronary tree leading to small but transmural myocardial infarction [2].

Based on the literature, there is some evidence strongly supporting the diagnosis of CE. Shibata et al. integrated these conventional findings as major and minor criteria, which include: angiographic evidence of $\mathrm{CE}$ and thrombosis without atherosclerotic components, concomitant multiple sites coronary artery embolisation or/and concomitant systemic embolisation excluding left ventricular thrombus due to AMI, evidence of an embolic source based on imaging examination, presence of embolic risk factors, and absence of significant stenosis at the culprit lesion after thrombus aspiration [3]. It is possible that these features will be adopted to prospective, validated criteria for clinical diagnosis of coronary artery embolism.

There is no consensus about optimal treatment of patients with CE. It is clear that the choice of the appropriate method of treatment should be individualised. However, it seems obvious that the management should be aimed at removing the source of embolism and prevention of further thromboembolic events. Nowadays there is no doubt that arteriography should be performed in all suspected acute coronary syndromes. Taking into consideration previously published studies, the choice of appropriate method of treatment depends on both the aetiology of embolus and its location in the coronary arteries. Manual thrombus aspiration has been shown to be a feasible and effective strategy for the treatment of CE-related infarction, especially if followed by histological examination of the thrombus [32]. In some cases, a smaller inner lumen diameter of aspiration catheters makes them less useful for aspirating large thrombi
[33]. Moreover, the major disadvantage of thrombus aspiration is its limited access to small and often tortuous vessels, where the emboli are usually located. Thus, in the case of total coronary artery occlusion, percutaneous transluminal coronary angioplasty (PTCA) should be considered. In most described cases angioplasty alone is effective enough and there are no indications for stent implantation. It is worth noting that these interventions are frequently complicated by moving occlusive embolus more distally, resulting in no reflow with suboptimal reperfusion [7, 15, 34]. As for the group of patients with patent foramen ovale, manual aspiration thrombectomy with or without angioplasty and stenting is the standard practice. Oral anticoagulation should be managed due to the risk of venous origin of thrombus [35]. Secondary prevention means also percutaneous or surgical closure of the right-to-left communication. A recent meta-analysis of three large randomised controlled trials of patients with a PFO found that percutaneous PFO closure with medical therapy, when compared with medical therapy alone, showed a trend toward reducing the recurrence of thromboembolic events (mainly stroke and TIA) [36]. In another study, which compared the efficacy of different devices in percutaneous closure of a PFO, lower recurrent neurological event rates with Amplatzer compared with CardioSeal-STARflex and Helex devices were demonstrated [37]. Although not proven, it is possible that these findings could be extrapolated to AMI due to CE. Neisius et al. reported a case series where age, recurrent pregnancy, poor compliance, and patient choice were all factors determining the choice of percutaneous PFO closure over lifelong oral anticoagulant therapy [24]. Also, surgical management of CE caused by IE, atrial tumours, or left ventricular aneurysm should receive early consideration [31]. It has been demonstrated that in patients with IE thrombolytic therapy should be avoided. There are several reports that warn clinicians about the risk of cerebral and systemic haemorrhage after thrombolytic agents have been given for AMI associated with endocarditis $[27,38]$. In these cases, intra venous antibiotics and surgical replacement of the infected valve are recommended methods of treatment. However, in addition to those methods for treatment of CE, many researchers mention the role of longterm anticoagulation in reducing the incidence of further embolism.

The prognosis for CE depends on many factors. Because of the fact that patients without pre-existing ischaemic heart disease have poorly developed collaterals, it is commonly believed that CE more often leads to sudden death than coronary thrombosis in patients with atherosclerosis [2]. In addition, patients susceptible to thromboembolism have many coexisting comorbidities (i.e. arrhythmia, cardiomyopathy, or valvular heart disease). Probably this is the reason 
why 5-year rates of all-cause death and cardiac death in the CE group are unexpectedly high. However, 30day cardiovascular mortality in the CE group is significantly lower than in patients with AMI due to atherosclerotic coronary artery disease [3]. It is notable that recurrent CE occurred particularly in AF patients with inadequate INR. Shibata et al. revealed the median time to a second episode of CE or thromboembolism in the study population was 35 months [3].

Coronary embolism should be considered in all cases of AMI in patients without atherosclerotic coronary artery disease. Over the years, the most common cause of CE has changed. Also, with the development of invasive methods of diagnosis and treatment, we know more about the managing in AMI due to coronary embolism. As long-term outcomes indicate, CE patients represent a high-risk subpopulation of patients with AMI and therefore require close follow-up.

\section{Conflict of interest}

The authors declare no conflict of interest.

\section{References}

1. Waller BF, Fry ET, Hermiller JB, Peters T, Slack JD. Nonatherosclerotic causes of coronary artery narrowing. Part I. Clin Cardiol 1996; 19: 509-12.

2. Prizel KR, Hutchins GM, Bulkley BH. Coronary artery embolism and myocardial infarction. Ann Intern Med 1978; 88: 155-61.

3. Shibata T, Kawakami S, Noguchi T, Tanaka T, Asaumi Y, Kanaya T, Nagai T, Nakao K, Fujino M, Nagatsuka K, Ishibashi-Ueda H, Nishimura K, Miyamoto Y, Kusano K, Anzai T, Goto Y, Ogawa H, Yasuda S. Prevalence, clinical features, and prognosis of acute myocardial infarction attributable to coronary artery embolism. Circulation 2015; 132: 241-50.

4. Hamman L. Coronary embolism. Am Heart J 1941; 21: 401-22.

5. Wenger NK, Bauer S. Coronary embolism. Am J Med 1958; 25: 549-57.

6. Loire R, Dubreuil C, Perrin A. Coronary emboli. Study of a series of 30 anatomo-clinical cases. Arch Mal Coeur Vaiss 1977; 70: $1-7$.

7. Camaro C, Aengevaeren WRM. Acute myocardial infarction due to coronary artery embolism in a patient with atrial fibrillation. Neth Heart J 2009; 17: 297-9.

8. Chugh SS, Blackshear JL, Shen WK, Hammill SC, Gersh BJ. Epidemiology and natural history of atrial fibrillation: clinical implications. J Am Coll Cardiol 2001; 37: 371-8.

9. Hamm CW, Bassand JP, Agewall S, Bax J, Boersma E, Bueno H, Caso P, Dudek D, Gielen S, Huber K, Ohman M, Petrie MC, Sonntag F, Uva MS, Storey RF, Wijns W, Zahger D; ESC Committee for Practice Guidelines. ESC guidelines for the management of acute coronary syndromes presenting without persistent ST-segment elevation. Eur Heart J 2011; 32: 2999-3054.

10. Chen JY, Zhang AD, Lu HY, Guo J, Wang FF, Li ZC CHADS(2) versus CHA(2)DS(2)-VASc score in assessing the stroke and thromboembolism risk stratification in patients with atrial fibrillation: a systematic review and meta-analysis. J Geriatr Cardiol 2013; 10: 258-266.

11. Lane DA, Lip GY. Use of the CHA(2)DS(2)-VASc and HAS-BLED scores to aid decision making for thromboprophylaxis in nonvalvular atrial fibrillation. Circulation 2012; 126: 860-5.

12. Bakalli A, Georgievska-Ismail L, Koçinaj D, Musliu N, Krasniqi A, Pllana E. Prevalence of left chamber cardiac thrombi in patients with dilated left ventricle at sinus rhythm: the role of transesophageal echocardiography. J Clin Ultrasound 2013; 41: 38-45.

13. Koniaris LS, Goldhaber SZ. Anticoagulation in dilated cardiomyopathy. J Am Coll Cardiol 1998; 31: 745-8.

14. Roudaut R, Serri K, Lafitte S. Thrombosis of prosthetic heart valves: diagnosis and therapeutic considerations. Heart 2007; 93: 137-42.

15. Tang L, Hu XQ, Zhou SH. Coronary artery embolism causing acute myocardial infarction in patients with mechanical heart valve prosthesis: which is the optimal treatment? Heart Lung Circ 2014; 23: 422-7.

16. Kiernan TJ, Flynn AMO, Kearney P. Coronary embolism causing myocardial infarction in a patient with mechanical aortic valve prosthesis. Int J Cardiol 2006; 112: 14-6.

17. Staico R, Armaganijan L, Lopes RD. Coronary embolism and calcified aortic valve: is there a correlation? J Thromb Thrombolysis 2012; 34: 425-7.

18. Mansur AJ, de Miranda RC, Grinberg M, Bellotti G, Pileggi F. Calcific aortic stenosis presenting as acute myocardial infarction. J Cardiovasc Surg 1990; 31: 310-2.

19. Shanoff HM, Balshin B. Coronary embolism in rheumatic heart disease. Can Med Assoc J 1962; 87: 5-8.

20. Rigatelli G, Rigatelli G, Rossi P, Docali G. Normal angiogram in acute coronary syndromes: the underestimated role of alternative substrates of myocardial ischemia. Int J Cardiovasc Imaging 2004; 20: 471-5.

21. Wachsman DE, Jacobs AK. Paradoxical coronary embolism: a rare cause of acute myocardial infarction. Rev Cardiovasc Med 2003; 4: 107-11.

22. Velebit V, al-Tawil D. Myocardial infarct in a young man with angiographically normal coronary arteries and atrial septal defect. Med Arh 1999; 53: 33-6.

23. Crump R, Shandling AH, Van Natta B, Ellestad M. Prevalence of patent foramen ovale in patients with acute myocardial infarction and angiographically normal coronary arteries. Am J Cardiol 2000; 85: 1368-70.

24. Neisius U, Northridge DB, Cruden NL, Denvir MA. Myocardial infarction associated with patent foramen ovale and paradoxical embolism: a case series. Int J Cardiol 2015; 180: 34-37.

25. Hakim FA, Kransdorf EP, Abudiab MM, Sweeney JP. Paradoxical coronary artery embolism - a rare cause of myocardial infarction. Heart Views 2014; 15: 124-6.

26. Roxas CJ, Weekes AJ. Acute myocardial infarction caused by coronary embolism from infective endocarditis. J Emerg Med 2007; 40: 509-14.

27. Brunson JG. Coronary embolism in bacterial endocarditis. Am J Pathol 1953; 29: 689-701.

28. Loire R, Tabib A. Coronary embolism. Apropos of 61 anatomoclinical cases [French]. Arch Mal Coeur Vaiss 1985; 78: 821-7.

29. Maqsood K, Sarwar N, Eftekhari H, Lotfi A. Septic coronary artery embolism treated with aspiration thrombectomy: case report and review of literature. Texas Heart Institute J 2014; 41: 437-9. 
30. Charles RG, Epstein EJ, Holt S, Coulshed N. Coronary embolism in valvular heart disease. QJ Med 1982; 51: 147-61.

31. Charles RG, Epstein EJ. Diagnosis of coronary embolism: a review. J Royal Soc Med 1983; 76: 863-9.

32. Kotooka N, Otsuka Y, Yasuda S, Morii I, Kawamura A, Miyazaki S. Three cases of acute myocardial infarction due to coronary embolism: treatment using a thrombus aspiration device. Jpn Heart J 2004; 45: 861-6.

33. Stoel MG, von Birgelen C, Zijlstra F. Aspiration of embolized thrombus during primary percutaneous coronary intervention. Catheter Cardiovasc Interv 2009; 73: 781-6.

34. Hernández F, Pombo M, Dalmau R, Andreu J, Alonso M, Albarrán A, Velázquez MT, Tascón JC. Acute coronary embolism: angiographic diagnosis and treatment with primary angioplasty. Catheter Cardiovasc Interv 2002; 55: 491-4.

35. Wilson AM, Ardehali R, Brinton TJ, Yeung AC, Vagelos R. Successful removal of a paradoxical coronary embolus using an aspiration catheter. Nat Clin Pract Cardiovasc Med 2006; 3: 633-6.

36. Pickett CA, Villines TC, Ferguson MA, Hulten EA. Percutaneous closure versus medical therapy alone for cryptogenic stroke patients with a patent foramen ovale: metaanalysis of randomized controlled trials. Texas Heart Inst J 2014; 41: 357-67.

37. Hornung M, Bertog SC, Franke J, Id D, Taaffe M, Wunderlich N, Vaskelyte L, Hofmann I, Sievert H. Long-term results of a randomized trial comparing three different devices for percutaneous closure of a patent foramen ovale. Eur Heart J 2013; 34: 3362-9.

38. Di Salvo TG, Tatter SB, O'Gara PT, Nielsen GP, DeSanctis RW. Fatal intracerebral hemorrhage following thrombolytic therapy of embolic myocardial infarction in unsuspected infective endocarditis. Clin Cardiol 1994; 17: 340-4.

\section{Addres for correspondence:}

Małgorzata Zachura MD

$2^{\text {nd }}$ Department of Cardiology

Świętokrzyskie Cardiology Centre

ul. Grunwaldzka 45, 25-736 Kielce, Poland

Phone: +48 507371694

E-mail:m.swiader@interia.pl 